\title{
Tourist-oriented approach in linguistic mediation
}

\author{
Elena A leksandrova ${ }^{1, *}$, Olesya A fanaseva ${ }^{1}$ \\ ${ }^{1}$ M urmansk Arctic State University, 15, Kapitana Egorova, 183038, M urmansk, Russia
}

\begin{abstract}
The article discusses strata of linguistic changes imposed by the necessity to meet the demands of the local tourism market illustrated by the flow of visitors to the Russian A rctic, namely to the M urmansk Region. The authors highlight grammatical and lexical changes on interlingual and intralingual levels, whereas cultural references are distinguished as a separate stratum due to their intrinsic characteristics. The definition of a cultural mediator is introduced in the article in contrast to those of a translator and a tour guide. It specifies the qualifications, skills, competences and language fluency level within the framework of the tourism-oriented approach. Tourism potential of the M urmansk R egion as a major part of the Russian A rctic shapes the long-term development strategy in the regional economy, in particular, enterprises policies, facility building and renovation, providing conditions appealing to not only local but national and international stakeholders and ultimately the vocational education and training system in tourist sector.
\end{abstract}

\section{Introduction}

Russia shares presence in the Arctic with Canada, the USA, Iceland, Norway, Denmark, Finland, Sweden and Greenland. Unlike some of the above-mentioned countries, Russia has vast territories above the Arctic Circle represented by seven Russian regions ranging from 144,902 to 1,095,609 square kilometres. Russian Arctic has attracted visitors from different parts of the world thus becoming the key destination of Arctic tourism and affecting many processes in the regions involved. For many years tourists from different countries have come to the Murmansk region for different purposes:

- fishermen from the USA, the UK and many European countries are attracted by the summer fishing opportunities of the multiple rivers all over the region;

- summer navigation brings cruise liners with international tourists to the port of Murmansk for one-day sightseeing trips;

- proximity of Scandinavian countries accounts for a big amount of visitors round the year.

Recent years have seen a dramatic increase in the number of tourists from Asia who visit the region mostly in winter, with February being the busiest month. The main attraction for this new group of visitors is the unique natural phenomenon - Aurora Borealis, or the Northern light, called Northern Lights by the locals - a natural light display in the sky usually seen in the high-latitude regions around the Arctic and Antarctic. The tourists are attracted not only by the beauty of the phenomenon but also by the myths of different nations connected with it appearing in the sky. Some aboriginal peoples believed that ghostly spirits spoke to people through the auroras; modern myths promise every Chinese who has seen the Aurora eternal harmony for themselves and many future generations to come; a more extreme legend states that a child conceived on the night when Aurora appeared in the sky will definitely be a boy. According to the Russian Tourism Association, every year the number of visitors coming to the region for the purpose of seeing the Northern lights grows by 20 to 30 per cent $[1,2]$. This group of tourists brought about certain steps to provide cultural adaptation of the business sector (announcements in Chinese in the airports, menus at the cafes in English and Chinese, information points where information is provided in different languages).

Different flows of tourists bring about the demand for specialists whose competences can be described between those of a guide, translator and advisor - a cultural mediator who can adapt the information and the language level for the recipients depending on their needs. As the origins of tourists differ (from Chinese to English native speakers), the main language of cross-cultural communication in the tourist sector is English. It is taught as a foreign language in most schools and in higher education institutions, and can be used as a lingua franca in different communication situations.

\section{Theoretical frame of tourist-oriented approach}

Tourist industry involves a wide range of different professions. According to the Russian Federal Law FZ132 of November 24, 1996 on Basics of Tourist Activities in the Russian Federation, the following occupations can be named: guide, translator-guide, instructor-guide [3]. A guide is a qualified professional who introduces the guests to the attractions. A translator-guide is a qualified professional who speaks a foreign language fluently enough to introduce the guests to the attractions. An instructor-guide is a skilled professional who is

\footnotetext{
* Corresponding author: aevea@ mail.ru
} 
responsible for the safety and security of the guests while on tours.

Tourist industry stakeholders give a more comprehensive description of a translator-guide specifying such skills as being a personal communicator who avoids word-forword translation but interprets the sense. They can perform additional functions such as giving advice on how to act in certain situations considering the cultural peculiarities of the country. Another function might include the personal assistance when needed.

In due course, the Polar Tourism Guides Association states that polar guide competences include:

- natural and cultural history interpretation based on the ability to learn, teach and share stories, which plays the critical role in polar tourism;

- customer service and group management, i.e. those which include but are not limited to solving problems and establishing consensus among divergent interests, keeping guests motivated and interested, being aware of individual needs within the realms of regulation, law and safety [4].

As practice shows, a new type of occupation emerges on the tourist market which comprises the skills and functions of the above mentioned professions. It can be defined as a cultural mediator who is accountable for providing a safe interesting stay of the guests in a country without facing any communication difficulties imposed by the lack of culture and language knowledge. The social benefit of masterful mediation is immeasurable as the values and norms that define the local culture and language are shaped and supported by the work performed by cultural mediators. For example, mediators have to consider the difference in calendars in different cultures: Russia counts years according to the Gregorian calendar while Thailand, for example, uses the Buddhist calendar. It means that the information about the foundation of Murmansk in 1916 will not be correctly understood by the Thai people, hence, it is wise to refer not to the year but to the period which passed between the foundation and the present: Murmansk was founded 103 years ago. The same strategy would be true for the natives of some Islamic countries, Ethiopia etc.

\section{Linguistic constraints: characteristics and solutions}

In modern linguistics the notion of constraints is widely used to represent properties an object or a notion must satisfy. Constraints can be general (or universal), valid for different languages, and very specific, representing a given language [5]. This article looks at the linguistic constraints that are conditioned by the peculiarities of the communication in the tourist sphere. These constraints are influenced by such factors as the nationality, age, occupation, aim and cultural background of the visitors, and result in certain interlingual changes in the tourist discourse, that is those which are caused by contact between speakers of different languages using a third language (English in this case) as a means of communication. In due course, interlingual changes bring about intralingual changes appearing in the Russian language due to external causes.

\subsection{Intralingual changes}

Tourist flows affect the way objects are specified in the vocabulary. The phenomenon, which attracts the tourists to the region, has been called the Northern Lights for many years by the locals. When the flow of tourists from Asia increased the above-mentioned word combination was substituted by the word Aurora, though with certain peculiarities: the word borealis meaning northern was dropped as it was difficult to pronounce for non-English speakers. The word Aurora grew in use in different spheres of the region being used in advertisements, hashtags, brand names and tour descriptions. Though initially used only in English-speaking discourse, it gradually appeared in the Russian language communication. The Russian word Aвpopa (Russ. Aurora) is a feminine noun requiring the pronoun она (Russ. she) and consequently associates with females inherent features.

Example: Russ. Пришла ненадолго, поманила, поиграла, подразнила и сбежала. (She came for a flick of a moment only playing, tempting, luring and teasing, and fled).

Russ. Mь давно знакомы. Найдет минутку для меня. (We've known each other for a long time. She'll find some time for me).

Russ. Смеялась, играла. Скоро проматься до осени. (She laughed and played. We'll have to say goodbye till autumn soon).

Further personification invests Aurora with inherently female descriptions:

Russ. Скромная, тихая, легкая. (Bashful, quiet and ethereal) [6].

Aurora Hunting. Aurora hunting is often advertised by the tourist companies as the highlight and main activity of the tour. The Murmansk Region residents treated the appearance of Aurora as a sign of the weather change and never looked for it on purpose. Though every time it came to the night sky, they saw some magic in it which is proved by multiple legends and myths of all the Northern peoples. As the tourist interest in Aurora grew, there appeared a new term Aurora Hunting which was correspondingly translated into Russian and is now reflected in many cases of use:

Example: Russ. Где сегодня лучше охотиться? A вы где сегодня охотитесь? Удачной охоты! (Which is the best place to hunt for Aurora today? Where are you going to hunt today? Good luck with the hunting!

A set of derivatives from the verb to hunt (as in the expression to hunt for Aurora) appeared in the Russian language and grew in use in different spheres of the tourist industry: Hunter (Russ. охотник), hunting (Russ. охота). These derivatives are mostly used in collocations with the word Aurora. The expressions are not completely assimilated in the Russian language yet: originating from the English expression Aurora hunting they are still more often used as охота за северным сиянием, охотники за северным сиянием (meaning that the first part of the 
expression was translated from English and the second part still retains the Russian traditional name for the phenomenon).

The tendency for the change can be observed in the social media which are nowadays the main source of information and, correspondingly, the first source to reflect the linguistic changes long before they are codified in dictionaries and corpora. Thus, if you search for the expression охота за северным сиянием, the hits that the search engine will show would include websites of tourist companies, descriptions of tours etc. It should be noted, though, that the same websites will have aurora hunters hashtags. At the same time, a similar search in social media and messengers (Facebook, Twitter, Telegram, Instagram etc) would show many results for the hashtag охотники за Авророй.

As the representatives of the tourist companies are looking for new ways of attracting tourists, they are coming up with new metaphors for describing the process of looking for Aurora both in Russian and in English:

Example: We provide a full range of trips to all mustsees of the Kola Peninsula: Aurora chasing trips...

Russ. в погоне за Авророй [6].

Experienced Aurora hunters. Do you wish to see it live?

Russ. застать Аврору врасплох [7].

So, we can say that intralingually the changes refer mostly to the vocabulary level: shift in the use of vocabulary units, formation of derivatives and metaphorisation.

\subsection{Interlingual changes}

Interlingual changes can be observed in the use of simplified English when translating oral texts and adapting (1) vocabulary and (2) grammar structures to make them clearer to understand for non-English speakers when used as a lingua franca [8].

(1) Adapting vocabulary. Since most of tourists speak little English and can understand only a limited vocabulary, incomprehensible words and word combinations naming native and indigenous notions (e.g. local geographical features, special equipment, flora and fauna) or professional terminology (e.g. medical and legislative terms) are either substituted with the words close in meaning or are explicitly defined.

For example, the elk which is found in the Murmansk Region is very often oddly referred to as a moose with this being wrong, though very close in meaning. Adapting the Russian name of the animal (Russ.) лось to a limited vocabulary understood by the tourists, the mediators have to use the English word moose instead of the English word elk to invoke required associations. Elk and moose belong to the same deer family. However, most of the tourists are unaware of the existence of the elk, and consequently of this word, because the moose is the largest division and the more popular specie of the two. Another example of avoiding vocabulary that might be difficult for non-native English speakers is using the word horns instead of antlers when translating the Russian word (Russ) poza. There is a very distinct difference between horns and antlers.
Antlers are grown by males of the Cervidae family, which includes all species of deer and elk, but the English word antlers has to be substituted with a better known one horns.

Another strategy of adapting vocabulary consists in generalizing words which might be misunderstood by the non-native speakers of English. The history of the Murmansk Region is closely connected with the history of Great Patriotic War (1941-1945) and is reflected in monuments, street names etc. E.g. Russ. Памятник вочнам 6-й Герочческой комсомольской батарее; Памятник воинам 1-го корпуса противовоздушной оборонь where Russ. батарея and Russ. корпус are types of military divisions in Russia which are specific to the Russian army can be referred to as Monument to the Heroic Komsomol soldiers and Monument to Air Defense Forces.

(2) Simplifying grammar structures. Among the most typical simplifications the following can be named:

- the Past Simple Tense instead of the Present and Past Perfect Tenses;

- the Present Simple Tense instead of the Present Continuous Tense;

- the Simple Future Tense instead of the Future Continuous and the Future Perfect Tense;

- dropping the articles;

- $\quad$ preference of Active Voice;

- the past participle is used only as an adjective: either with a noun or after the verbs "to be, to become".

Thus, to be better understood the mediators have to use the verb in the following grammar forms only: the infinitive, the simple present, past or future tense, and the past participle (as an adjective); changing passive constructions to active and keeping the sentences short (20 words max).

\subsection{Cultural references}

Strategies applied in translating cultural references traditionally apply either foreignization or domestication while tourist discourse calls for another strategy - cultural adaptation which is neither of the two above mentioned. Within the framework of theoretical research translation strategies to deal with cultural references are divided into two umbrella translation strategies: direct and oblique translation $[9,10]$. They cover a range of procedures:

Table 1. Umbrella translation strategies

\begin{tabular}{|l|l|}
\hline $\begin{array}{l}\text { Direct } \\
\text { translation }\end{array}$ & $\begin{array}{l}\text { Oblique } \\
\text { translation }\end{array}$ \\
\hline borrowing & transposition \\
\hline calque & modulation \\
\hline $\begin{array}{l}\text { literal } \\
\text { translation }\end{array}$ & equivalence \\
\hline & adaptation \\
\hline
\end{tabular}

Cultural references require special attention when the information is provided to the tourists whose native culture is different from that of Russia. A good example of adapting cultural references for the tourist group can be illustrated by one which requires explication as word-forword translation would be impossible because of the 
peculiarities of the Russian word-building: certain suffixes are used to form colloquial nouns which in due course serve as locally specific names for some places:

- $\quad$ Russ. Воняловка (a stinking place) - the name of a creek and the area around it which was used as a place for picnics after which people left much garbage, hence, the smell;

- $\quad$ Russ. Мордобойка (a place where you can get beaten up) - the nickname of the only café in one of the districts of Murmansk which served beer back in the 1970-s where a lot of fights started between the visitors. Later the name was given to the surrounding area;

- Russ. Нахаловка (a place of insolent ones) - an area where in the 1920-s the first inhabitants of Murmansk started illegal construction of houses.

Such names raise interest of the tourists as they give them a feeling of the place itself the way it is perceived by the locals. That is why it is important to give the visitors at least a general idea of the place name and its origin, so, cultural adaptation can serve this purpose $[11,12]$.

Adaptation as a term encompasses different translation situations which vary from situational equivalence, to localisation, to creative addition. Cultural adaptation involves rethinking the whole discourse for either objective (lack of time during the bus trip) or subjective (nationality or background of certain visitors) purposes. These constraints influence the choice of translation and adaptation procedures applied for culture specific references which also depend on the communication situation and include the following procedures:

- official translation;

- calque;

- explication;

- generalisation by hypernym;

- concretisation by hyponym;

- substitution;

- lexical recreation;

- compensation;

- elimination;

- creative addition.

The choice of a certain procedure depends entirely on the experience and skills of the cultural mediator who can evaluate both objective and subjective constraints and make the right decision.

\section{Discussion}

Being a part of the Russian Arctic, the Murmansk Region is enjoying increased tourist inflows. Tourists come from all over the world (the USA, the UK, Canada, Thailand, Taiwan, China etc.) and pursue different purposes, which range from seeing the polar lights and ice-fishing in numerous local lakes to getting onto the icebreaker in Murmansk port to continue their way to the North Pole. The local tourist sector has to be flexible to meet the needs of different categories of tourists. Thus, challenges posed on local tour guides involve also those of a translator and an instructor. As a result of the combination of these three professions a new occupation appears on the market of the region. It can be defined as a cultural mediator, the one who takes account of the language understood by the tourists as well as of the cultural differences. Adapting both to the needs of a particular tourist group is one of the main responsibilities, which a cultural mediator has. The English language used as a lingua franca to communicate with non-native speakers undergoes lexical and grammatical changes investigated in the article. Moreover, English vocabulary used in the tourist sector affects that used by the local people in their own language. Another important issue that has to be taken into account by the cultural mediator is dealing with cultural references which consists in choosing the right adaptation strategy.

To meet the requirements of the modern tourist market the educational establishments of the regions should collaborate with the representatives of the tourist industry in order to adapt their educational programmes to the needs of the professional market. Such adaptation should turn the educational process from traditional one to the tourist-oriented approach.

\section{References}

1. S. Pyatakov, Vzglyad, Murmansk, Russia appeals to Chinese tourists. Retrieved from: https://vz.ru/economy/2017/9/1/885188.html (2017)

2. RF Tourism Association analytical data. Retrieved from:

https://www.atorus.ru/ratings/presentation_analitics.h $\underline{\mathrm{tml}}(2019)$

3. FZ-132 On tourism standards in RF (amended). Retrieved from: http://base.garant.ru/136248/ (1996)

4. Polar Tourism Guides Association. Official website: https://polartourismguides.com (2019)

5. P. Blache Constraints, Linguistic Theories, and Natural Language Processing In: D.N. Christodoulakis (eds) Natural Language Processing - NLP 2000. Lecture Notes in Computer Science, 1835. Springer, Berlin, Heidelberg, 221-232

6. Aurora Hunting Tours. Murmansk. Services and fees. Retrieved from: https://www.aurorahuntingtour.ru/?lang=en (2019)

7. The Northern Lights Tour. Kola Peninsula of Russia, Murmansk city. Retrieved from: https://nordtours.ru/en/ (2019)

8. E. Shohamy, S. Waksman Linguistic landscape as an ecological arena. Modalities, meanings, education, In Linguistic landscape. Expanding the scenery, 313 330, (Oxon: Routledge, 2009)

9. J.-P Mailhac The formulation of translation strategies for cultural references. In C. Hoffmann (Ed.), Language, culture and communication in contemporary Europe 132-151 (Clevedon: Multilingual Matters, 1996)

10. I.Ranzato The Translation of Cultural References in the Italian Dubbing of Television Series (Imperial College London, 2014), 93-102

11. S. Taviano English as a Lingua Franca: Implications for Translator and Interpreter Education, The interpreter and translator trainer, 7 (Routledge, 2014), 155-167 
12. W. Baker Culture and Identity through English as a Lingua Franca: Rethinking Concepts and Goals in
Intercultural Communication, DELF, 8 (Walter de Gruyter GmbH \& Co KG, 2015), 5-12 